\title{
Researcher-led academic development
}

Ian Kinchin a , Marion Heron*a, Anesa Hosein ${ }^{\text {a }}$, Simon Lygo-Baker ${ }^{\text {a }}$, Emma Medland ${ }^{\mathrm{a}}$, Dawn Morley ${ }^{\mathrm{b}}$, and Naomi Winstone ${ }^{\mathrm{a}}$.

a. Department of Higher Education, University of Surrey

b. Solent Learning and Teaching Institute, Solent University, Southampton

*Corresponding author:

Marion Heron

Department of Higher Education

University of Surrey

Guildford

GU2 5XH

m.heron@surrey.ac.uk

\section{Researcher-led academic development}

\section{Abstract}

In this study, members of a higher education department explore their research activity and how it influences their practice as academic developers in a researchled institution. Whilst the research activities of the team members appear diverse, 
they are all underpinned by a shared set of professional values to provide an anchor for these activities. Research-as-pedagogy and the relationship between the discourses of research and teaching are explored using Bernstein's knowledge structures. The authors conclude that differences in research focus (horizontal discourse) provide dynamism across a department and that stability is provided through the underpinning core values inherent in the vertical discourse.

Key words: academic development; horizontal discourse; research frame; values; vertical discourse

\section{Introduction}

There is a tension within academic development centres about the nature of the role and whether it should be undertaken by research-active academics, or by colleagues who are seen solely as service providers working on non-academic (not research active) contracts (Fraser \& Ling, 2014; Kensington-Miller, Renc-Roe \& Moron-Garcia, 2015). The study described in this paper has been undertaken within a department where engagement in research is seen as a vital component of the academic developer profile, and therefore considers the influence of the personal research focus of each of the research-active members of a department, the way in which it underpins perceptions of their role as academic developers, and their professional practice with staff and students. We make the assumption that in the context of a research-led institution, the influence of research needs to be explicit in our 'development' role. Teaching and learning in the institution are supported by a shared understanding of factors such as the regulative discourse, pedagogy and discipline, research-teaching nexus, and locus of control. Without explicit research frames, academic development as an activity is in danger of inhibiting cohesion and coherence across these factors, leading to a condition termed pedagogic frailty (see Kinchin \& Winstone, 2017).

We situate this paper within the wider debate around the research-teaching nexus and in particular the notion of how being 'research active' allows the academic developer to provide 'insights into various experiences' (Griffiths, 2004, p. 721) in their work with staff and students. Within the various paradigms of the research-teaching nexus identified by Griffiths (2004), historically much academic development has been a combination of research-led and research-informed, that is, drawing from key theories that have informed higher education, such as 'reflective practice', 'deep-surface learning' and 'constructive alignment' (see Kandlbinder \& Peseta, 2009). Whilst the programmes developers deliver may contribute to the development of academics' identities as teachers (van Lankveld, et al, 2017), it is possible that they contribute to the perceived split between teaching and research. However, within a department that is actively researching teaching practice, there is likely to be a shift from the above paradigms to a more research-oriented approach in which academic developers embody their own research tradition within their practice - in the form of researcher-led teaching (sensu Hay et al, 2015). We argue that researcher-led teaching is more likely to afford opportunities for sharing experiences and common ground with staff, as well as giving credibility to the academic developers within the institution (Healey, 2005). In this paper, we explore how our research frames guide our academic development activities. We explore our diverse researcher-led academic development practice guided by the theoretical frame provided by Bernstein's knowledge structures (Bernstein, 1999; 2000), who described the vertical (or regulative) discourse as considering the 
underpinning values of teaching and the horizontal discourse focussing on the content being covered. We suggest that an academic development unit which explicitly models both a diversity of research frames for pedagogic research and a set of shared values can enrich the learning experience of the staff we work with (Griffiths, 2004).

\section{Context}

This paper takes as its starting point that in order to understand how academic developers work together as a group and view their roles, it is important to explore the research lens through which they base their practice with others - in particular how they explore teaching with staff/students. Such an exploration inevitably involves an examination of identities as academic developers. Academic developers have many different roles and identities depending often on the institution and the tasks they are involved in, the 'home' discipline from which they have migrated (most academic developers started their careers in another discipline and migrated into academic development), and the fragmentary nature of academic practice is something that has been problematized by Gough (2014). Sugrue, Englund, Solbrekke and Fossland (2017) suggest that a research and scholarship approach towards examining the roles and responsibilities of academic developers may provide the 'pivotal glue' (p.12) necessary to further develop the field and better understand academic developer identity.

This paper further explores the 'nexus of academic development' (Leibowitz, 2014, p. 359) - the learning from teaching, research, and vice versa, which informs and enhances our work with others. Although Gravett (2017) states 'what educational developers promote is also, over time, what we developers come to embody ourselves' (p. 9), we argue that, in fact, the starting point for our teaching is the embodiment of our own values about teaching and learning and our research focus. Similarly, we started from our position as researchers and looked outwards to explore how our research frame influences our academic development role and, in particular, our interactions with staff (cf. Kinash \& Wood, 2013). Ultimately, the knowledge of academic developers is 'produced by practitioners, about themselves, their theories-in-use, organizational structures and values' (Clegg, 2009, p. 409).

We start from the premise that 'more contextualised and qualitative approaches are necessary to gain a more comprehensive insight into [academic developers'] $\mathrm{s}$ practice' (Sugrue et al, 2017, p. 4). In this study, we offer a rich and detailed account of the practices of six academic developers in one single department. The overall profile of the department fits within the 'family portrait' of academic developers identified by Green and Little (2016). Colleagues represented here have first degrees in psychology (2), political science, engineering, nursing, and applied linguistics and many have doctorates in education or education-related areas. The academic developers in this study worked with staff across the university on established programmes for earlycareer academics which aimed to develop understanding and skills of professional practice in a higher education context. This academic development role also involves mentoring inexperienced staff through teaching practice, and mentoring more experienced staff in their development for professional recognition (e.g. Senior Fellowship of the Higher Education Academy).

\section{Methods}

In order to stimulate and frame narrative reflections on their work, the participants in this research were each asked to engage in a single map-mediated interview. By 
employing map-mediated interviews (Kandiko and Kinchin, 2012), where the interviewer is an experienced concept mapper, the process is able to guide the interviewee to produce high quality concept maps (i.e. they are clear, concise, and highly explanatory). This is not by suggesting content to add, but by interrogating the map to ask the interviewees if they could produce a link with greater explanatory power. Some of the interviewees also needed confirmation that it was possible to stop when the map had expressed everything they felt was important. In this way, the interviews yielded excellent maps (as described by Kinchin, 2016; Cañas et al, 2017) - analogous to collecting a rich interview transcript. The concept maps were intended to be concise, clear, explanatory, and balanced, so that they would be able to act as effective prompts for the interviewee to use them to frame their developing narrative about the researchteaching relationship and to sensitise them to the possible connections between ideas. Concept maps should not be viewed as simple summary diagrams but as tools in the exploration of the relationship between ideas that are represented and as a stimulus for dialogue (e.g. Wilson et al, 2016). Due to the exploratory nature of this study (looking at identifying connections between concepts), the use of concept maps to represent individual perceptions was considered to be particularly appropriate here. They are dynamic constructs rather than static representations. In recent years, the focus of concept mapping studies has started to shift from the representation of agreed, curriculum knowledge, towards the representation of the theories and values that underpin teaching (e.g. Lygo-Baker, Kingston \& Hay, 2008; van den Bogaart et al, 2017; McMillan \& Gordon, 2017).

The interview question was simple: to 'describe the dominant research frame that guides your practice as an academic developer'. This process produced a concept map for each of the six interviewees, summarising their research frame in a format that was succinct and emphasised the dynamic links between the identified elements. Each of the interviewees was interviewed by an 'expert mapper' so that they could concentrate on the answer to the question whilst the mapper could guide the interrogation of their evolving map and help to ensure the map was succinct whilst exhibiting the maximum explanatory power (Heron, et al 2018). During the interviews, maps were physically constructed using Post-It notes and A3 paper. Completed maps were drawn electronically by the interviewer and returned to the interviewee for editing/refinement before inviting them to offer a reflective narrative to highlight and explore key points from the map. The first-listed co-author acted as the interviewer. The maps and the associated narratives (provided in italics below) form the data for this study from the six co-authors who acted as interviewees for this analysis. The narratives were analysed for themes relating to values and beliefs about teaching and learning. 


\section{Results}

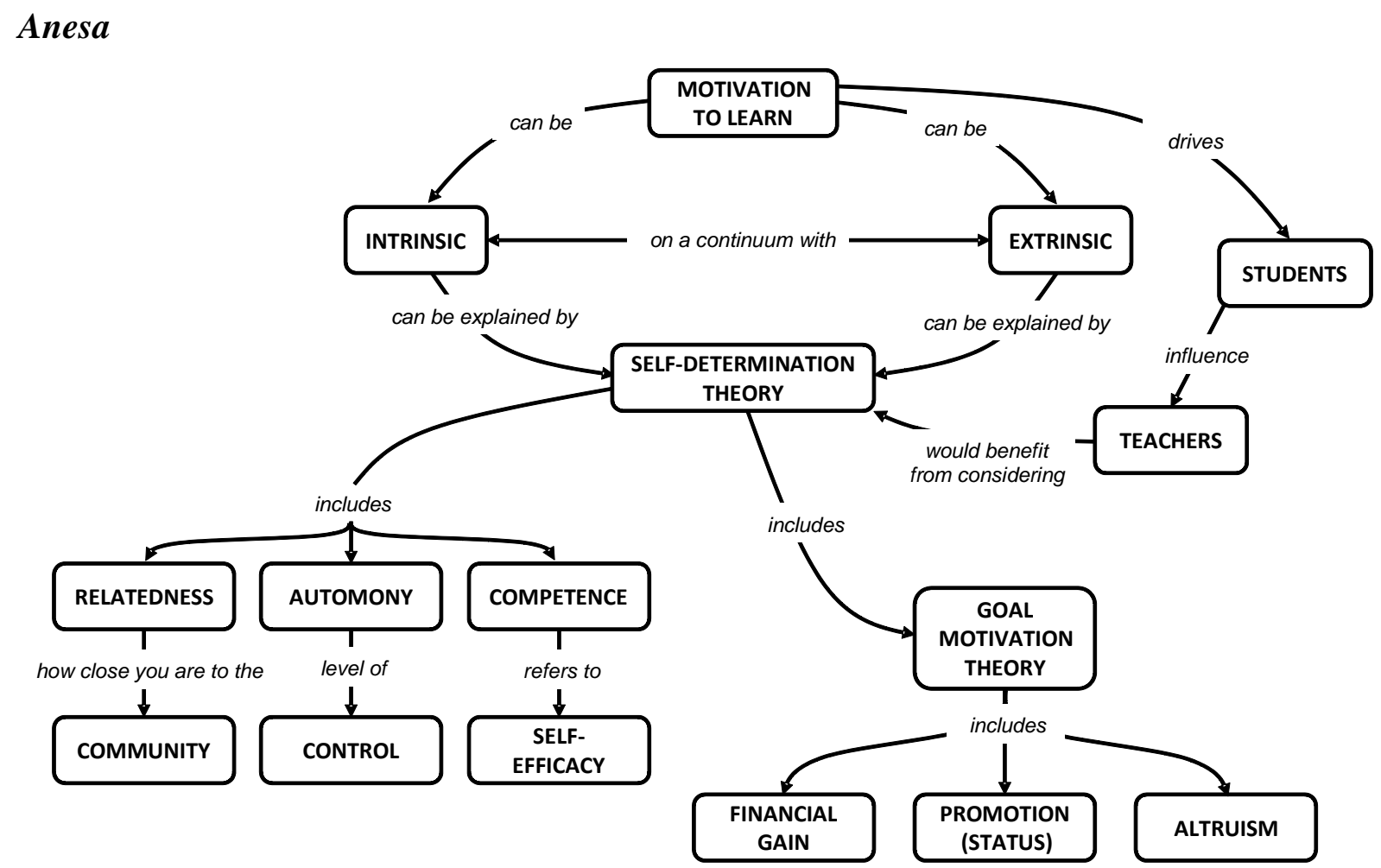

Figure 1: Anesa's research frame.

As an academic developer, I distinguish my job role into two parts, one as an academic development researcher $(A D R)$ and the second as an academic development facilitator $(A D F)$. I view both of these roles as being research-integrated on the research-teaching nexus, that is, my "pedagogical research, disciplinary knowledge, disciplinary research and pedagogical knowledge are merged" (Hosein, 2017, p. 145).

As an ADR, I have drawn on a number of psychological theories to explore my own and other's teaching as well as students' learning including deep/surface approaches to learning (Marton \& Säljö, 1976), selfefficacy (Bandura, 1986) and self-regulation (Zimmerman, 1990) as these are on my PhD and post-PhD research. Recently, I was introduced to self-determination theory (SDT) by another ADR which I saw as an all-encompassing theory that could incorporate all of these frames I had used previously to guide me in how I think about learning and teaching. SDT is framed within the psychological discipline and is based on the notion of intrinsic and extrinsic motivation (Ryan \& Deci, 2000). I help my tutees to deconstruct their students' engagement through the lens of SDT (see also Kahu, 2013; Trowler, 2010). For example, I often speak about two types of students (as two extremes rather than as a dichotomy); those who are interested and love a subject area and will automatically engage with the subject (that is, they are intrinsically motivated) and those who do not love the subject but are doing the subject for an alternative end goal, such as employability (extrinsically motivated) and are less likely to engage with the subject area. Those students who are intrinsically motivated will more likely engage in deep learning than those who are extrinsically motivated (see Vansteenkiste, Lens, \& Deci, 2006). Therefore, I explore with my tutees how 
they can engage their extrinsically motivated students by finding out what their students' interests are (i.e. relatedness). Through this, my tutees can create circumstances to tap into their students' extrinsic motivation by making students feel they are making a conscious choice (having autonomy) to engage with these subjects to meet their aspirations (see Ryan \& Deci, 2000).

Dawn

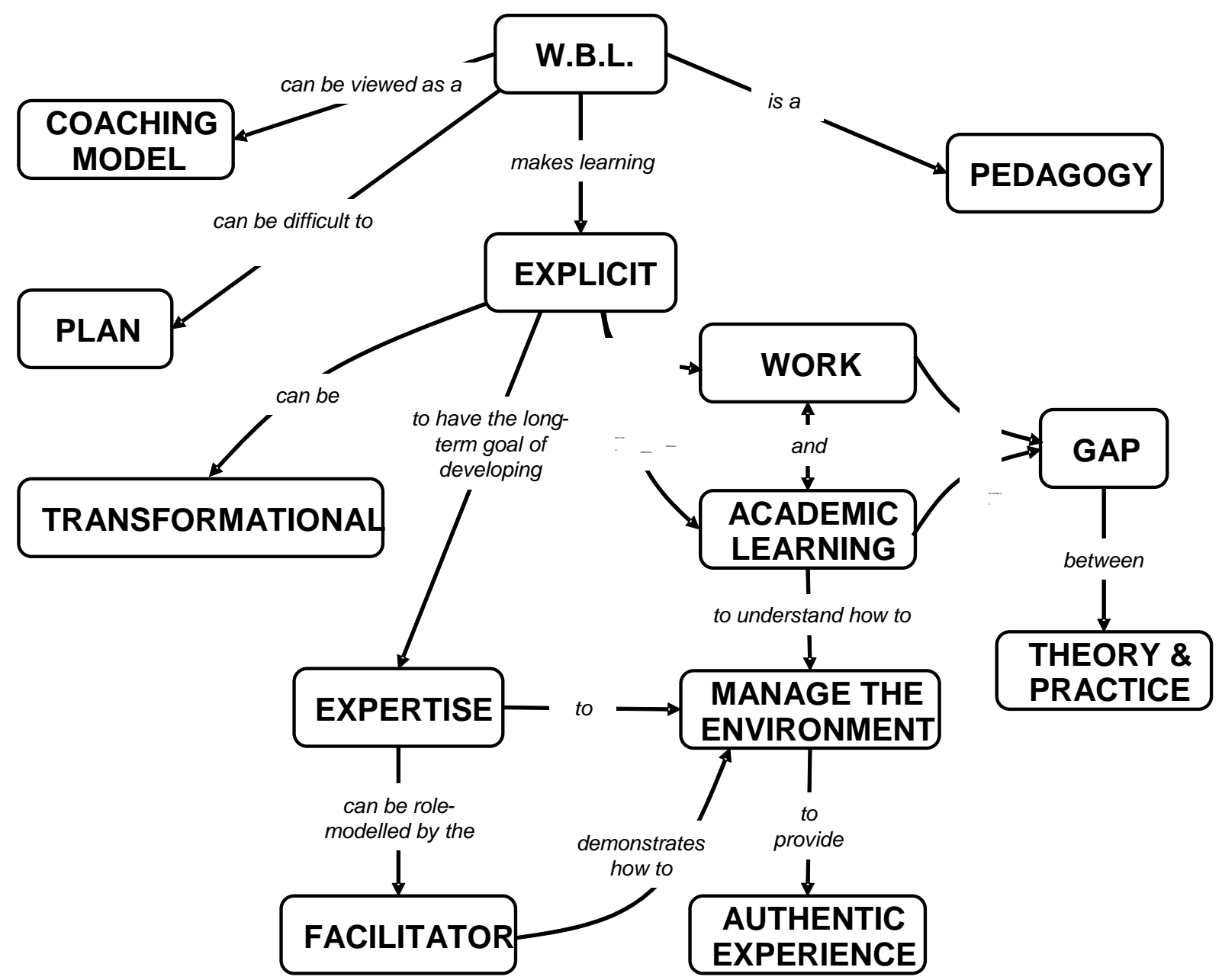

Figure 2: Dawn's research frame

My research interests within work-based learning (e.g. Boud \& Solomon, 2001, Morley 2018) have had a significant impact on my style of teaching and how to best support colleagues undertaking our own teaching courses.

The premise of work-based learning is that both student and teacher are working in a predominantly unstructured learning environment. The advantage for learning is that students can grow their knowledge, skills, and attitudes more quickly for this is a testing place where they are less protected and controlled than during their traditional university experience. The teachers also have greater diversity, realising that multiple people in the work setting offer access to different aspects of practice and knowledge. For students, the light bulb moments of learning can be intense, transforming their identities forever.

The courses we run also strongly recognise the ethos of collaborative learning from peers in a diversity of disciplines. The group work I facilitate reminds me of the work-based setting-knowledge growing quickly and organically with group members connecting how they can improve the learning experience for their own students. This is exciting learning, drawing on the expertise and creativity of all the group members. The ability to coach our learning groups uses similar facilitation skills to those developed in the work setting. Making learning explicit is important so that good ideas are captured and not lost in the energy of 
the debate. The role of the teacher also must change, "the guide on the side", so students feel able to express their thoughts and opinions in a safe and encouraging environment.

The disadvantage of work-based learning is that there can be a significant gap between practice and theory. Knowing this, I continually try to blend pedagogic theory with real life experience of teaching; looking for those "war stories" that give students insight and perhaps those light bulb moments of learning that are so impactful.

\section{Emma}

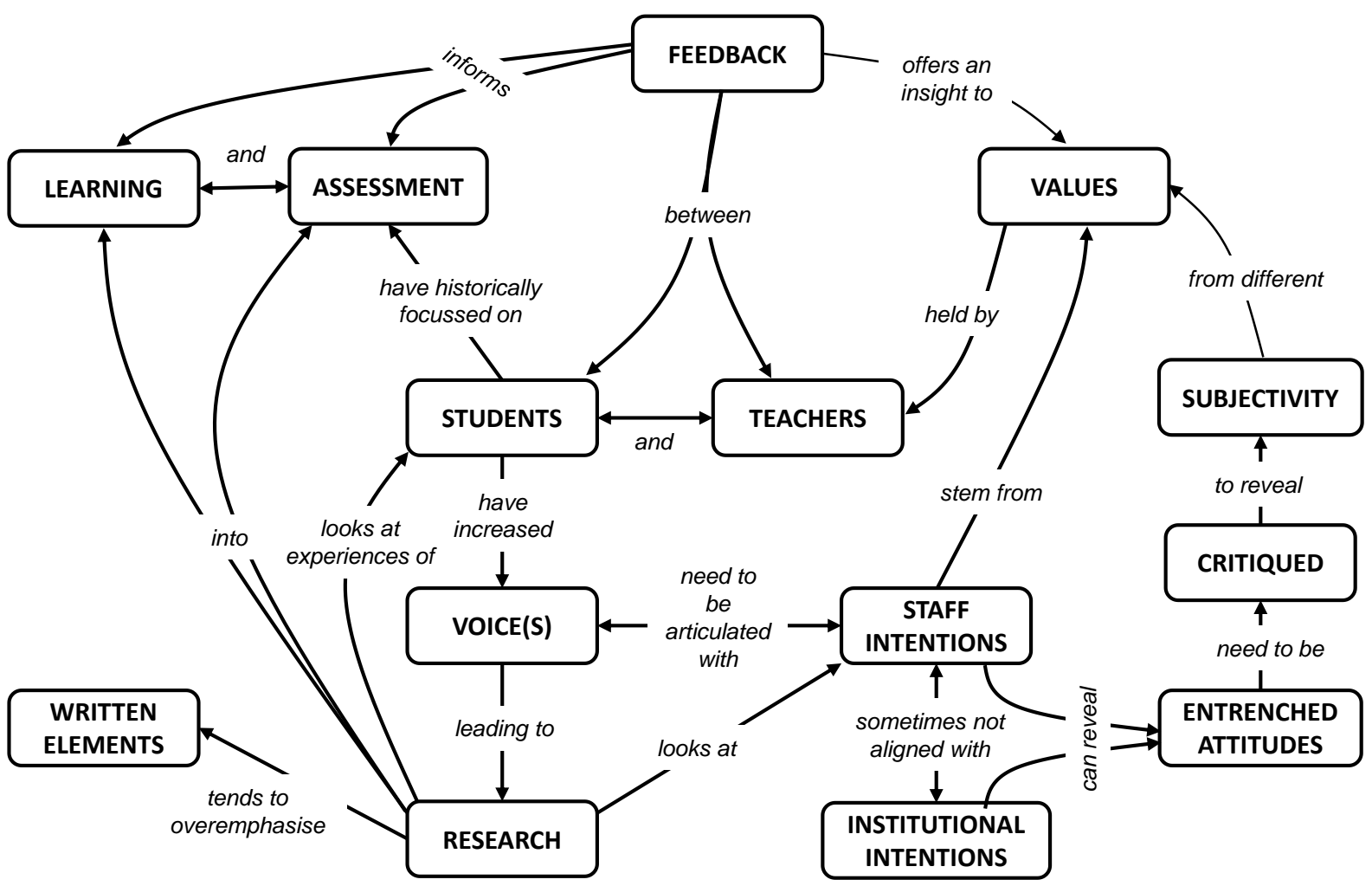

Figure 3: Emma's research frame.

The burgeoning assessment and feedback literature asserts its centrality to learning, and yet it is an aspect of their learning experience that HE students are often least satisfied with (e.g. Evans, 2013). Figure 3 highlights the fundamentality of feedback, in particular, to my understanding of pedagogy. It offers insight into the often tacit values underpinning practice and the potential for illuminating these values through discussion between stakeholders (e.g. marking partners, students, external examiners etc.). It may be used as a tool to make explicit the learning journey from novice to expert and to scaffold learning in a manner that gives voice to teachers and students. However, it is not restricted to assessment alone and lives within the dialogue of teaching and learning (although will not always be perceived as feedback within this context). In essence, it is an act that goes beyond formal education and underpins learning in general. Within an HE setting, the value of feedback is all too often overlooked due to the entrenched attitudes associated with its role in curriculum development - as an afterthought. Increasing workloads can result in its perception as a time consuming aspect of teaching that students fail to engage with. Nevertheless, feedback is identified as integral to learning and, despite the influx of research, contains a number of underresearched areas that are central to my research and pedagogic practice.

When assessing work, I am keenly aware of what I have learnt through researching and teaching assessment and feedback (e.g. Medland 2015; 2016). As a result, I feel that it is important to practice what I preach to ensure the integrity of my practice. My understanding of the feedback process and what effective feedback involves must therefore be reflected in the feedback comments provided. However, feedback lives not only within my assessment practices, but also within my pedagogic practice. On a more explicit level, my research informs the focus of my teaching, and implicitly underpins the manner in which I teach. 
Feedback as part of the dialogue of teaching is used to support participants to articulate the values that underpin their intentions and the challenges faced when this does not align, or conflicts with the broader institutional intentions.

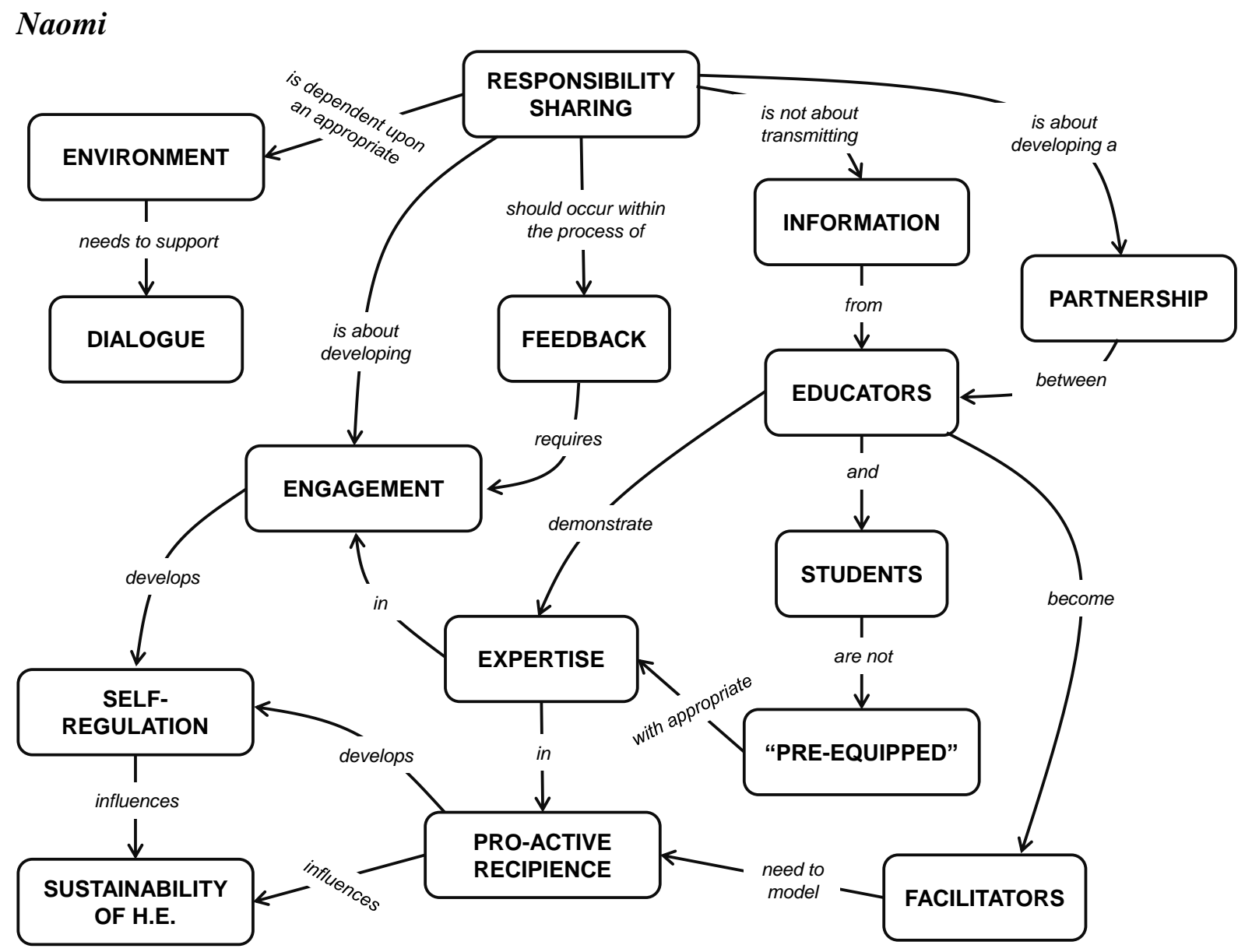

Figure 4: Naomi's research frame

I believe that academic development encompasses a process of enactment. When facilitating the development of others in their teaching, it is essential that we espouse an approach to teaching and learning that draws upon a strong evidence base. This is afforded extra credibility when that evidence base includes contributions from our own work. A further consideration involves modelling the enactment of regulations and institutional procedures.

As someone relatively new to academic development, having come from an Associate Dean (Learning and Teaching) role, I have felt this challenge keenly. I now realise that the academic development role sits in a position of tension when enacting regulations and policies. Should we be models of best practice in adhering to regulations, or should we perhaps push boundaries and show that there are other ways of doing things? Either way, authenticity and credibility are key. Part of this credibility comes from the fact that we are also academics, and have to manage tension in the research-teaching nexus in much the same way as participants on our programmes.

The core value underpinning the research that I do is that of responsibility sharing. My work on assessment feedback explores student engagement with feedback (e.g. Winstone, Nash, Rowntree \& Parker, 2017), and 
considers how staff and students hold equal responsibility for making the process work (e.g. Nash \& Winstone, 2017). I bring this approach to my work with participants on our programme by discussing the shared responsibility between myself and the group in supporting their development. My research on student engagement with feedback also incorporates themes of dialogue and partnership; feedback is not a one-way transmission of information, but an ongoing process of dialogue that supports the development of both feedback giver and recipient. In a similar vein, when working with participants, I feel it is important to not simply 'give' information and guidance, without any ongoing dialogue. I believe that transformative learning is most likely to occur where focus is placed not on the input in terms of the information given to students, but on the output, in terms of how behaviour, attitudes, and approaches to teaching change as a result of on-going processes of dialogue.

In my work on assessment and feedback, I focus also on the development of self-regulation in students. A similar principle applies to work with novice teachers; rather than giving them simple tips that they can apply to their current context, the aim is to give them the skills to constantly modify and update their teaching approach in new and un-encountered situations.

\section{Simon}

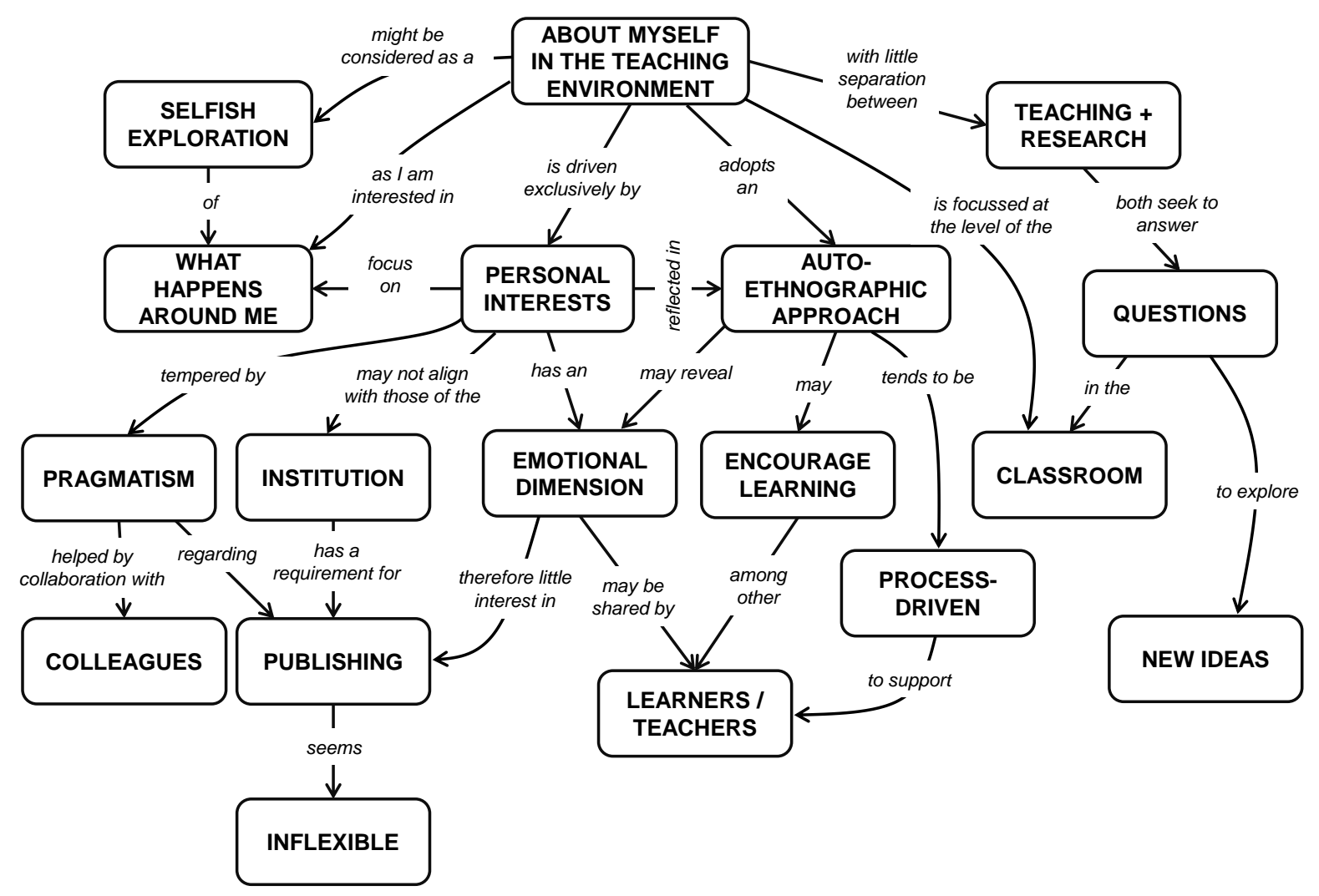

Figure 5: Simon's research frame.

I find it unhelpful to separate the teaching and research; for me the two are inextricably linked. The map (Figure 5) tries to portray this. My interest comes from my desire to understand what is happening around me in the learning environment where my role as an academic developer plays out. It is essentially fuelled by what I would call a selfish exploration (a personal value) but also one based on a pragmatism that relates to being bounded by what I can and cannot influence (a social value). This to me does not produce a typical definition of selfish but an open and honest one. I am interested by what happens in and around me and understanding why I react as I do, and how others respond. In one sense I know a little about why but ultimately I can never really know as it is too complex, I think. As a result for me, and ultimately I think this is what underpins my map, is that I can interrogate myself and 'what' and 'why' I do what I do, and I can ask relevant, interesting and useful questions. I don't think this can always relate to or be useful to others as a product. What I can help with is to support others with the process and if it resonates help them to develop relevant and useful questions for themselves, although ultimately that is for them. I think that is 
what defines my approach:the development of questions as a teacher and as a researcher. I think that is why there is a trade-off. To do this selfish thing, which I believe is all I can actually do, I have to publish. For me the aim of that would be to develop a conversation to help others see what they could ask themselves, because the results of my explorations are bounded in my own context and experience. For me, I think this is why I have discomfort if research is divorced from the personal event-the fact the outcome is rarely a conversation, it is a one-off artefact that seems suspended from reality and not embedded in anything useful. I have to do it in the sense that it allows me to then go back to what I like doing which is exploring what is going on around me. What might not come across in the map is I think that my approach is constantly evolving and therefore stopping at one point for me seems of little value and interest -it seems immediately past and therefore a historical fact and I am more interested in what is next. What I know now as a researcher of my teaching is that I know very little and have more questions to explore.

\section{Marion}

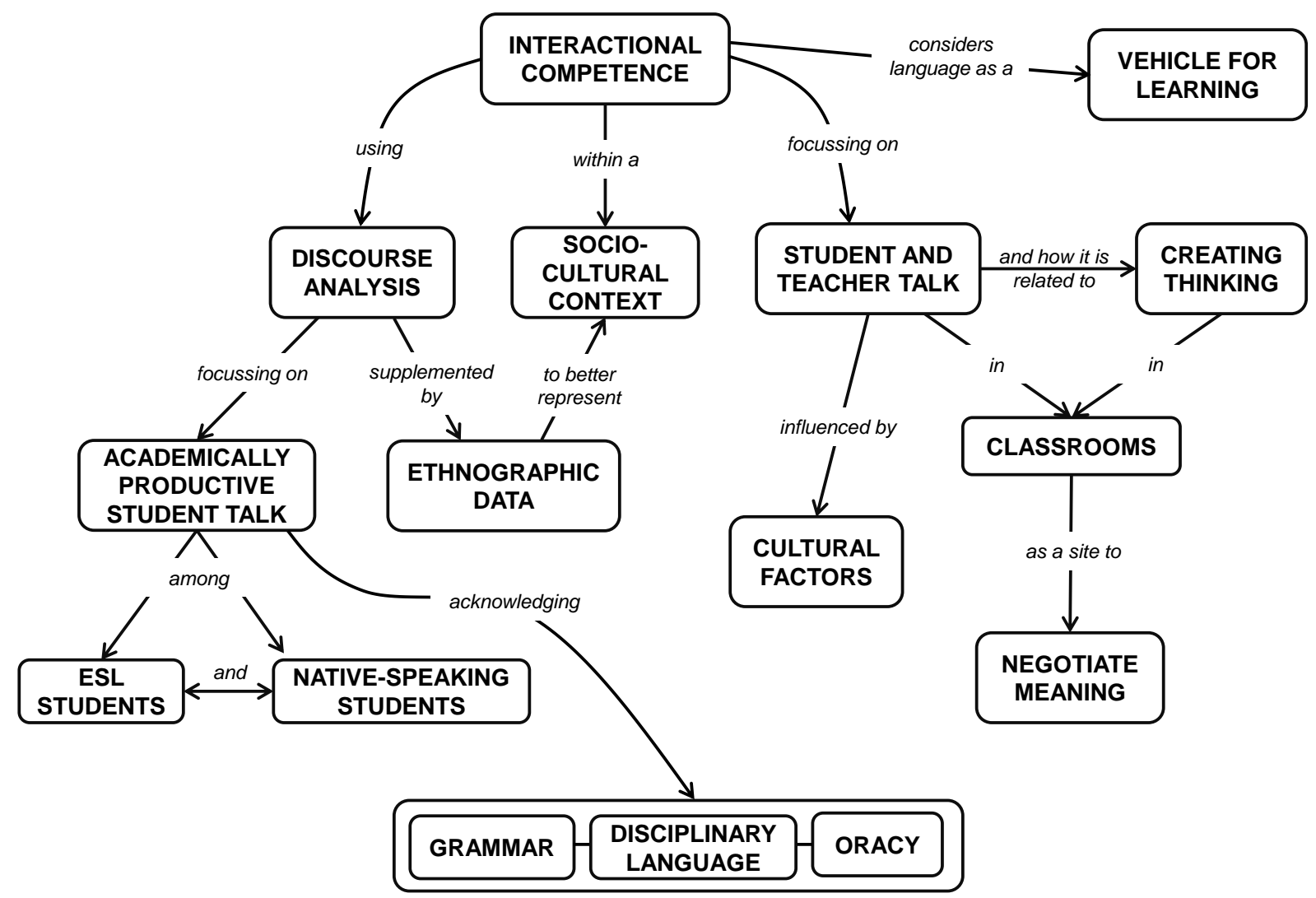

Figure 6: Marion's research frame.

The notion of research frame is particularly relevant when I consider how my own research lens gives shape to and strengthens my work as a teacher. My research perspective holds true for all teaching contexts. My focus of interest, research, and the basis of my teaching philosophy, is the central role of language, particularly talk, in learning (Walsh, 2012). A fundamental belief is that learning is enhanced when classroom talk and pedagogic goals align. Teachers use talk to carry out oral tasks such as explaining, organising, and instructing. Teachers also use talk to scaffold learning and support thinking, often referred to as dialogic teaching (Alexander, 2008), an approach which harnesses "the power of talk to shape knowledge" (Barnes, 2010, p. 7), challenge students' thinking, and elicit articulation of these thoughts. Similarly, classroom discourse also encompasses the talk that students use with peers and with the teacher. Learners use talk to co-create meanings through justifying, explaining, and reasoning. Underpinning the ability to use this exploratory talk (Mercer, 2000) are effective oracy skills.

My research perspective on classroom talk forms the basis of how I view learning and therefore how I explore teaching with my students. Since interactional competence is central to learning, I ensure that interaction and talk are evident in my curriculum, my pedagogy, and my assessment. For example, I use many different discussion activities in my teaching that encourage the use of certain types of talk. I also 
believe in explicitly teaching language to support academically productive talk. Students need to be made aware of how to use language effectively and need input on specific phrases to use in discussion that will support them both linguistically and cognitively. My research perspective also informs my own professional development.

\section{Discussion}

This study aimed to explore how our research frames guide our academic development activities and practice. From the concept maps and narratives it can be seen that whilst the research foci of the participants exhibit variability in scope and methodological preference, the work of each of the researchers is underpinned by a number of core values that are shared across the group. For example, individual maps and narratives identify concepts such as motivation, work-based learning, and assessment and feedback as key to the academic developers' research activity, yet evident in all the concept maps were values relating to the relationship between students and teachers, the nature of professional development, the sociocultural context, and a shared approach to facilitating learning. In Bernsteinian terms (Bernstein, 1999; 2000), these observations suggest that even if the transitory, horizontal discourse exhibits variation across the team, the vertical discourse reveals shared values and beliefs. Stability in the usually tacit, vertical, or regulative discourse would appear to be the more important component in developing departmental cohesion. We talk about our values and the ways in which we draw ideas from our research frames to inform our practice as academic developers ideas we embody within our practice through 'sharing responsibility', 'providing feedback' or 'self-reflection' and 'role-modelling' for example. Participants on academic development programmes may have a richer experience as a result of the sharing of both the discipline of our research - pedagogy - as well as our explicit values as researchers.

The 'target' for academic development seems to be 'teaching excellence' (Holt, Palmer \& Challis, 2011), though this is a term that is considered by some to lack any real meaning as there is no agreed definition (e.g. see Charles, 2018; Stevenson, Whelan $\&$ Burke, 2017). The target of academic development is therefore, not fixed, and resides in numerous different disciplinary contexts. The whole enterprise is quite fluid and therefore each of the participants has to exhibit a degree of flexibility in their approach. Flexibility in the horizontal may be separate from a well-established vertical discourse.

Comments are made about the interaction of teaching and research and in many ways they embody the notion of 'research as pedagogy' in academic development (Kinchin, Kingsbury \& Buhmann, 2018). The relationship between teaching and research is complex and evolves through interaction with various collaborative networks (e.g. Rienties \& Kinchin, 2014; Rienties \& Hosein, 2015). Teaching networks tend to be strongest within an institution, whilst research networks are often across institutions and even international so that the twin roles identified by Anesa (academic development facilitator and academic development researcher) are complementary and mutually re-enforcing.

From the key concepts identified in the maps, it is evident that research is also coloured by each of our home disciplines, with the six interviewees here coming from Engineering, Political Sciences, Psychology (2), Nursing and Applied Linguistics. Disciplinary concepts identified in the maps include discourse analysis, selfdetermination theory, and self-regulation. These we see as supplying the 'resources' for academic development and providing a richer experience for the participants we work with in our professional development activities. 
Within a research-led institution it seems appropriate to also demonstrate an engagement in researcher-led academic development as a point of overlap between academic development and the scholarship of teaching and learning (Geertsema, 2016), particularly where there is a degree of discipline-sensitivity to academic development activities (e.g. Amundsen \& Wilson, 2012). However, merely referencing research that has been undertaken elsewhere seems to offer less authenticity of practice than drawing upon research that is currently being undertaken 'in-house'. The academic identities of those 'undergoing' academic development are strongly influenced by their research activities and their perceptions of the relative value of research over teaching (e.g. Young, 2006). For academic developers to exhibit a parallel values set represents an additional facet to the 'family portrait' of research-led academic development (as described by Green \& Little, 2016). To avoid setting up a system which creates a divide between academic developers and disciplinary academics - thus contributing to pedagogic frailty (Kinchin \& Winstone, 2017) - we argue that it is crucial for academic developers to embody their research within their teaching practice and make this explicit to staff with whom they practice.

\section{Conclusion}

We strongly agree with Stigmar \& Edgren (2017, p. 207) who state that 'staff at the academic development centres need to be research-active themselves to be able to support the development of such a scholarship in teachers from other disciplines'. Moreover, we also conclude that differences in research content provide diversity and dynamism across a department, but similarity in underpinning values creates consistency and resilience. We make a number of suggestions that may support the development and promotion of researcher-led academic development:

- Map-mediated conversations, such as the ones used in this study, can support deep awareness-raising across a department and make explicit the shared values that underpin practice.

- Academic contracts for academic developers are fundamental to provide insider support, credibility, and legitimacy for academic developers in a research-led institution.

- Explicit recognition of the academic developers' research perspectives should be made explicit to programme participants in order to share the vertical discourse of underpinning values. This awareness amongst participants can promote scholarly dialogue within our teacher development programmes.

\section{Biographies}

Marion Heron is Senior Lecturer in the Department of Higher Education at the University of Surrey. She is a Senior Fellow of the Higher Education Academy. She has worked in higher education in Turkey and the United Arab Emirates. She researches in the area of classroom talk and classroom interaction.

Anesa Hosein is a Lecturer in the Department of Higher Education at the University of Surrey. She is a Senior Fellow of the Higher Education Academy and member of the Research \& Development Committee of the Society for Research into Higher Education. She has worked in the higher education systems of the Caribbean and the UK. She has an eclectic collection of qualifications and an equally eclectic collection of 
research namely in academic practice, mathematics education, research methods pedagogy, educational technology, and migrant academics.

Ian Kinchin is Professor of Higher Education at the University of Surrey. He is engaged in the professional development of academic staff, whilst undertaking research into university pedagogy and the application of Novakian concept mapping. Ian is the editor of the Journal of Biological Education, a Fellow of the Royal Society of Biology, a Senior Fellow of the Higher Education Academy, and a member of the Governing Council of the Society for Research into Higher Education. He is currently developing a model for academic development that is framed by the concepts of pedagogic frailty and resilience.

Simon Lygo-Baker is a Senior Lecturer in Higher Education at the University of Surrey and has worked in academic development for over fifteen years. He has developed a range of academic programmes working across all disciplines, and undertaken significant research into learning and teaching, leading to a range of publications.

Emma Medland is a Lecturer in Higher Education at the University of Surrey. She is a Senior Fellow of the Higher Education Academy and has been a Lecturer for eleven years, working at Surrey and King's College London. She is currently the Programme Director of the MA in Higher Education and manages the provision of Continuing Professional Development workshops to support the pedagogic development of academic staff and those involved in supporting learning across the institution. Emma's research interests lie in assessment and feedback, and academic practice.

Dawn Morley is a post doctorate researcher at Solent University. Prior to her current position she was a Lecturer in Higher Education at the University of Surrey. Her work focuses on motivating and coaching staff to take their interest in learning and teaching 'one step further' into wider reaching projects and publications. Dawn is currently coleading the development of a new Educational Doctorate at Solent and the first open access Solent-led book on real world learning.

Naomi Winstone is a Senior Lecturer in Higher Education at the University of Surrey. Her research interests focus on cognition and learning, and the application of psychological theory to educational contexts. She is a Senior Fellow of the Higher Education Academy and a National Teaching Fellow.

\section{References}

Alexander, R. (2008). Culture, dialogue and learning: Notes on an emerging pedagogy. Exploring talk in school, 2008, 91-114.

Amundsen, C. \& Wilson, M. (2012) Are we asking the right questions? a conceptual review of the educational development literature in higher education. Review of Educational Research, 82(1): 90-126.

Bandura, A. (1986). Social Foundations of Thought and Action. New Jersey: Prentice-Hall, Inc.

Barnes, D. (2010). Why talk is important. English Teaching, 9(2), 7. 
Bernstein, B. (1999). Vertical and horizontal discourse: An essay. British Journal of Sociology of Education, 20(2), 157-173.

Bernstein, B. (2000) Pedagogy, symbolic control and identity. Oxford, Rowman \& Littlefield.

Boud, D., \& Solomon, N. (2001). Work-based learning: a new higher education? McGrawHill Education.

Cañas, A.J., Reiska, P. \& Möllits, A. (2017) Developing Higher-Order Thinking Skills with Concept Mapping: A Case of Pedagogic Frailty. Knowledge Management \& ELearning, 9(3): $348-365$.

Charles, M. (2018) Teaching in spite of Excellence: Recovering a practice of teaching-led research. Studies in Philosophy of Education, 37(1), 15 - 29.

Clegg, S. (2009). Forms of knowing and academic development practice. Studies in Higher Education, 34(4), 403-416.

Evans, C. (2013) Making sense of assessment feedback in higher education. Review of Educational Research, 83(1), 70 - 120.

Geertsema, J. (2016) Academic development, SoTL and educational research. International Journal for Academic Development, 21(2), 122 - 134.

Gough, M. (2014). The problem of identity for academic practice in terms of definition. Studies in Higher Education, 39(4), 590-607.

Gravett, E. O. (2017). Tracing a developer's development: a self-study in teaching. International Journal for Academic Development, 22(4), 307 - 318.

Green, D.A. \& Little, D. (2016) Family portrait: a profile of educational developers around the world. International Journal for Academic Development, 21(2), 135 - 150.

Fraser, K., \& Ling, P. (2014). How academic is academic development?. International Journal for Academic Development, 19(3), 226-241.

Griffiths, R. (2004). Knowledge production and the research-teaching nexus: The case of the built environment disciplines. Studies in Higher education, 29(6), 709-726.

Hay, D., Weller, S. \& Ashton, K. (2015) Researcher-led teaching: embodiment of academic practice. Higher Education Review, 48(1), 25 - 39.

Healey, M. (2005). Linking research and teaching to benefit student learning. Journal of Geography in Higher Education, 29(2), 183-201.

Heron, M., Kinchin, I.M. \& Medland, (2018) Interview talk and the co-construction of concept maps. Educational Research, In Prep.

Holt, D., Palmer, S., \& Challis, D. (2011). Changing perspectives: Teaching and learning centres' strategic contributions to academic development in Australian higher education. International Journal for Academic Development, 16(1), 5-17.

Hosein, A. (2017) The research-teaching nexus. In: Kinchin, I.M. \& Winstone, N.E. (Eds.) Pedagogic Frailty and Resilience in the University. (pp. 135 - 149) Rotterdam, Sense Publishers.

Kahu, E. R. (2013). Framing student engagement in higher education. Studies in Higher Education, 38, 758-773.

Kandiko, C.B. \& Kinchin, I.M. (2012) What is a doctorate? A concept-mapping analysis of process versus product in the supervision of lab-based PhDs. Educational Research, 54(1), 3-16.

Kandlbinder, P. \& Peseta, T. (2009) Key concepts in postgraduate certificates in higher education teaching and learning in Australasia and the United Kingdom. International Journal for Academic Development, 14(1), 19-31.

Kensington-Miller, B., Renc-Roe, J., \& Morón-García, S. (2015). The chameleon on a tartan rug: adaptations of three academic developers' professional identities. International Journal for Academic Development, 20(3), 279-290. 
Kinchin, I.M. (2016). Visualising powerful knowledge to develop the expert student: A knowledge structures perspective on teaching and learning at university. Rotterdam, Sense Publishers.

Kinchin, I.M., Hosein, A., Medland, E., Lygo-Baker, S., Warburton, S., Gash, D., Rees, R., Loughlin, C., Woods, R., Price, S. \& Usherwood, S. (2017) Mapping the development of a new MA programme in higher education: Comparing private perceptions of a public endeavour. Journal of Further and Higher Education, 41(2), 155-171.

Kinchin, I.M., Kingsbury, M. \& Buhmann, S.Y. (2018) Research as pedagogy in academic development. In: Medland, E., Watermeyer, R., Hosein, A., Kinchin, I. \& LygoBaker, S. (Eds.) Pedagogical peculiarities: Conversations at the edge of university teaching and learning. (pp. 49 - 67) Rotterdam, Brill/Sense Publishers.

Kinchin, I.M. \& Winstone, N.E. (Eds.) (2017) Pedagogic Frailty and Resilience in the University. Rotterdam, Sense Publishers.

Kinash, S., \& Wood, K. (2013). Academic developer identity: How we know who we are. International Journal for Academic Development, 18(2), 178-189.

Leibowitz, B. (2014). Reflections on academic development: what is in a name?. International Journal for Academic Development, 19(4), 357-360.

Lygo-Baker, S., Kingston, E. \& Hay, D.B. (2008) Uncovering the diversity of teachers' understanding of their role: The importance of individual values. The International Journal of Learning, 15(5), 245 - 253.

Marton, F., \& Säljö, R. (1976). On qualitative differences in learning I. Outcome and process. British Journal of Educational Psychology, 46, 4-11.

McMillan, W. \& Gordon, N. (2017) Being and becoming a university teacher, Higher Education Research \& Development, 36:4, 777-790

Medland, E. (2015) Examining the Assessment Literacy of External Examiners. London Review of Education, 13(3), 21-33.

Medland, E. (2016) Assessment in higher education: drivers, barriers and directions for change in the UK. Assessment \& Evaluation in Higher Education, 41(1): 81 - 96.

Mercer, N. (2000). Words and minds: How we use language to think together. Psychology Press.

Morley, D. (Ed.) (2018) Enhancing employability in higher education through work based learning. London: Palgrave MacMillan

Nash, R. A., \& Winstone, N. E. (2017). Responsibility sharing in the giving and receiving of assessment feedback. Frontiers in Psychology, 8, 1519.

Rienties, B., \& Hosein, A. (2015). Unpacking (in)formal learning in an academic development programme: A mixed-method social network perspective. International Journal for Academic Development, 20(2), 163-177.

Rienties, B., \& Kinchin, I. (2014). Understanding (in)formal learning in an academic development programme: A social network perspective. Teaching and Teacher Education, 39, 123-135.

Ryan, R. M., \& Deci, E. L. (2000). Self-determination theory and the facilitation of intrinsic motivation, social development, and well-being. American Psychologist, 55, 68-78.

Stevenson, J., Whelan, P. \& Burke, P.J. (2017), Teaching excellence' in the context of frailty In: Kinchin, I.M. \& Winstone, N.E. (Eds.) Pedagogic Frailty and Resilience in the University (pp. 63 - 77) Rotterdam, Sense Publishers.

Stigmar, M., \& Edgren, G. (2017). Performing research at university centers for academic development-an explorative case study in Sweden. International Journal for Academic Development, 22(3), 199-210. 
Sugrue, C., Englund, T., Solbrekke, T. D., \& Fossland, T. (2017). Trends in the practices of academic developers: trajectories of higher education? Studies in Higher Education, 1-18. https://doi.org/10.1080/03075079.2017.1326026

Trowler, V. (2010). Student engagement literature review. Higher Education Academy. York.

van den Bogaart, A. C., Schaap, H., Hummel, H. G., \& Kirschner, P. A. (2017). Combining concept maps and interviews to produce representations of personal professional theories in higher vocational education: effects of order and vocational domain. Instructional Science, 45(3), 359-376.

van Lankveld, T., Schoonenboom, J., Volman, M., Croiset, G., \& Beishuizen, J. (2017). Developing a teacher identity in the university context: A systematic review of the literature. Higher Education Research \& Development, 36(2), 325-342.

Vansteenkiste, M., Lens, W., \& Deci, E. L. (2006). Intrinsic Versus Extrinsic Goal Contents in Self-Determination Theory: Another Look at the Quality of Academic Motivation. Educational Psychologist, 41, 19-31.

Walsh, S. (2012). Conceptualising classroom interactional competence. Novitas-ROYAL (Research on Youth and Language), 6(1), 1-14.

Wilson, J., Mandich, A., \& Magalhães, L. (2016). Concept Mapping: A Dynamic, Individualized and Qualitative Method for Eliciting Meaning. Qualitative Health Research, 26(8), 1151 - 1161.

Winstone, N. E., Nash, R. A., Rowntree, J., \& Parker, M. (2017). "It'd be useful, but I wouldn't use it": Barriers to university students' feedback-seeking and recipience. Studies in Higher Education, 42(11), 2026-2041.

Young, P. (2006). Out of balance: lectures' perceptions of differential status and rewards in relation to teaching and research. Teaching in Higher Education, 11(2), 191-202.

Zimmerman, B. J. (1990). Self-regulated learning and academic achievement: an overview. Educational Psychologist, 25, 3-17. 